\title{
Water quality in three potential drought refuges in an arid-land river: assessing habitat suitability for at-risk fish species
}

\author{
David J. Van Horn ${ }^{1, *}$, Justin K. Reale ${ }^{2}$ (1) and Thomas P. Archdeacon ${ }^{3}$ (D) \\ ${ }^{1}$ Department of Biology, University of New Mexico, Albuquerque, New Mexico, USA \\ ${ }^{2}$ U.S. Army Corps of Engineers, Albuquerque, New Mexico, USA \\ ${ }^{3}$ U.S. Fish and Wildlife Service, New Mexico Fish and Wildlife Conservation Office, Albuquerque, New Mexico, USA
}

Received: 22 June 2021 / Accepted: 6 January 2022

\begin{abstract}
Drought is a common disturbance in arid-land streams and rivers. The survival of aquatic species depends on access to refuge habitats where water quality remains high. Over the past century, modified flow regimes and altered watershed and instream characteristics have led to the extinction and endangerment of numerous fish species endemic to the southwestern United States. We assessed the water quality of potential drought refuges in the Middle Rio Grande (MRG), with an emphasis on suitability for the endangered Rio Grande Silvery Minnow (RGSM). We examined three types of potential drought refuges: three agricultural return drain outfalls; three isolated pools that remained during streamflow intermittency; and a reach with perennial flow below an agricultural diversion dam. All potential refuges are known to contain RGSM and other fishes. Two out of three drain outfalls, one out of three isolated pools, and three out of ten kilometers of perennially wetted stream below a dam met basic water quality criteria necessary to support RGSM populations. These findings suggest that refuge habitability is context dependent, that generalizations regarding the suitability of a specific refuge type should be avoided, and that careful assessment is required to determine if a specific location will support fish assemblages. Although some areas may contain water, they may represent ecological traps if fish are exposed to poor water quality conditions compared to other potential refuge habitats.
\end{abstract}

Keywords: Arid-land river / fish habitat / refugia / water quality

\section{Introduction}

Drought is a common disturbance in lotic ecosystems, particularly in arid regions, that elicits a predictable cascade of impacts to affected streams and rivers (Leigh et al., 2015; Magoulick and Kobza, 2003; Rolls et al., 2012). Droughts decrease water quantity (Rolls et al., 2012), connectivity with other aquatic habitats (Perkin et al., 2015), and resource subsidies from upstream reaches (Leigh et al., 2015). Flow reduction also leads to changes in the quality of the remaining water, with impacts to water temperature (greater variability, more extreme highs and lows), dissolved oxygen (reductions during warm periods), $\mathrm{pH}$ (decreases when respiration rates are high), and nutrient availability (Leigh et al., 2015; Magoulick and Kobza, 2003; Rolls et al., 2012).

When droughts lead to river drying, the resistance and resilience of aquatic organisms depends on access to stream segments where water is persistent and where water quality is sufficient to support aquatic species. Drought refuges are broadly defined as zones in which the stressors associated with

\footnotetext{
*Corresponding author: vanhorn@unm.edu
}

disturbance are lower than those found in adjacent areas (Lancaster and Belyea, 1997). Examples of natural refuges include water holes that can persist for years in between surface flow events (Costelloe and Russell, 2014; Hamilton et al., 2005), alligator ponds (Parkos et al., 2011), saturated benthic sediments (Davey et al., 2006), and upstream and downstream perennial reaches (Davey and Kelly, 2007). A variety of anthropogenic habitats also provide refuge for aquatic organisms including drainage ditches (Colvin et al., 2009), waste water and associated water bodies (Halliday et al., 2015), and transport canals (Chester and Robson, 2013). Key characteristics that impact the habitat suitability of aquatic refuges include depth, riparian cover, and habitat complexity; however, optimum values of each of these characteristics are organism specific (Pires et al., 2010; Walters, 2016).

Aquatic refuges are particularly important in the southwestern United States where lotic habitats have been reduced by anthropogenic activities and climate change. These impacts are pronounced in the Rio Grande, the fifth longest river in the United States that drains over $550,000 \mathrm{~km}^{2}$ in eight states in two countries (Patiño-Gomez et al., 2007). Current flows from the northern branch of the Rio Grande are an estimated 95\% lower than under natural flow regimes and flood amplitudes 
have been reduced by $\sim 60 \%$ (Blythe and Schmidt, 2018). These alterations have shifted fish assemblages to more tolerant species (Hoagstrom et al., 2010). The Middle Rio Grande (MRG), the $\sim 300 \mathrm{~km}$ reach in New Mexico between Cochiti and Elephant Butte reservoirs, historically supported 27 species of fish (Cowley, 2006). Today, only 14 native species remain due to the extinction and extirpation of two and eleven native species, respectively (Cowley, 2006; Hoagstrom et al., 2010). One guild of native fish, the pelagic-broadcastspawning minnows, has been particularly impacted by these changes, both in the MRG and across the entire Great Plains region of the western United States (Worthington et al., 2018). In the Rio Grande, only one of five historically occurring species is currently extant, the endangered Rio Grande Silvery Minnow (RGSM, Hybognathus amarus (Bestgen and Platania, 1990). Other species from this reproductive guild including Notropis jemezanus, Notropis orca, Notropis simus, and Macrhybopsis aestivalis have been extirpated from the MRG.

Water is the most critical component of refuge for aquatic species. During streamflow intermittency, several habitats in the MRG retain water and may act as refuge for fishes including RGSM. First, a series of agricultural diversion dams direct water from the mainstem of the river into an extensive network of irrigation ditches. Excess irrigation water and seepage is collected in drains that discharge into the river prior to the next diversion dam, and these drain outfalls have been proposed as potential refuges in water-limited river reaches based on observations of RGSM and other fish species (Archdeacon et al., 2013; Cowley et al., 2007). Second, hundreds to thousands of isolated pools form seasonally in localized geomorphic depressions during drying events (Archdeacon and Reale, 2020). These areas provide refuge in other river systems (Costelloe and Russell, 2014; Hamilton et al., 2005; Marshall et al., 2016; Pires et al., 2014), where they can persist and support fishes for weeks, or even months to years (Hamilton et al., 2005; Hopper et al., 2020). Although nearly all isolated pools in the MRG persist only a few days (Archdeacon and Reale, 2020), RGSM are commonly found in these pools (Archdeacon, 2016). Finally, areas immediately downstream of the agricultural diversion dams maintain perennial flow due to contributions from leaking dam gates, seepage from nearby return drains and ditches, and shallow alluvial groundwater inputs, and are regularly inhabited by RGSM (Dudley et al., 2020).

While each of these potential refuge areas maintain water for at least some period following drying of portions of the mainstem of the river, little is known about the water quality in these habitats, how water quality varies spatially and temporally, and how the water quality in these areas compares to that in the portions of the mainstem of the river where flow is perennial. Evaluating water quality in each of these areas is important for understanding when and where aquatic refuge habitat occurs, and because a lack of suitable refuge can result in mortality of adults, hindering recovery efforts (Archdeacon et al., 2020; Vadas et al., 2016). Additionally, assuming that all wetted areas are equal could result in water management strategies that create ecological traps, which are defined as initially preferred habitats that undergo rapid environmental changes that make them unsuitable to support aquatic species (Vander Vorste et al., 2020). Municipal wastewater discharge is an example of an ecological trap, as it attracts fish with warmer temperatures in winter, but subsequently exposes individuals to pollutants (McCallum et al., 2019; Mehdi et al., 2021). Thus, understanding both how species use potential refuge habitats and critically examining the habitats themselves is important for advancing conservation of aquatic species (Zuñiga-Palacios et al., 2021).

The goal of this study was to assess water persistence and quality in these three potential refuge habitats in the MRG using a combination of discrete and continuous data collection to determine potential habitability for vulnerable fish species, with a particular emphasis on limits for the RGSM. The continuous data collection focused on temperature and dissolved oxygen, as these are essential for determining habitat suitability for fishes, and preliminary measures of critical thermal and oxygen thresholds exist for RGSM. We specifically tested if (1) values in the drain and pool refuge habitats differed significantly from those in the mainstem of the river and (2) if temperatures varied significantly along the reach below the irrigation diversion dam. We also collected discrete water chemistry data from isolated pools to determine if groundwater recharge occurs and to assess biogeochemical processes that may impact water quality in these potential refuges. Determining the habitability of these refuges is essential for developing management strategies for fish communities in the Rio Grande, particularly during years with minimal snowmelt runoff and extensive river drying.

\section{Study sites and methods}

\subsection{The Middle Rio Grande}

Agricultural diversion dams divide the Middle Rio Grande into four reaches (Fig. 1). The upstream Cochiti and Angostura reaches are perennial, however, sediment retention by Cochiti Reservoir has caused downcutting and armoring of the river bed and isolation from the flood plain, resulting in poor habitat and rapid downstream transport of eggs for the broadcast spawning RGSM (Dudley and Platania, 2007), with likely extirpation in the Cochiti Reach and low abundances in the Angostura Reach (Bestgen and Platania, 1991; Braun et al., 2015). The downstream Isleta and San Acacia reaches have sandy substrates, increased lateral connectivity, lower water velocities, and thus increased RGSM populations (Braun et al., 2015). However, these reaches are much more susceptible to drying due to intensive water extraction for agricultural use, with up to $80 \mathrm{~km}$ of drying occurring during some years (Archdeacon, 2016), representing $\sim 30 \%$ of the critical habitat for RGSM (federal register). The refuges assessed for habitability were all located in the two downstream reaches of the MRG.

\subsection{Agricultural return drains}

Water temperature and DO data were collected in agricultural return drains to compare conditions to those in the mainstem of the river and to determine if critical thresholds for RGSM survival are exceeded in these potential refuges. Sensors were deployed during summer months in three drains that discharge to the MRG in the Isleta Reach; the Sabinal $\left(34^{\circ} 31^{\prime} 37.3836^{\prime} \mathrm{N} ; 106^{\circ} 47^{\prime} 29.112^{\prime} \mathrm{W}\right)$, Lower Peralta 2 (LP2, $\left.34^{\circ} 35^{\prime} 26.4048^{\prime} \mathrm{N} ; \quad 106^{\circ} 44^{\prime} 50.0748^{\prime} \mathrm{W}\right)$, and Alejandro 


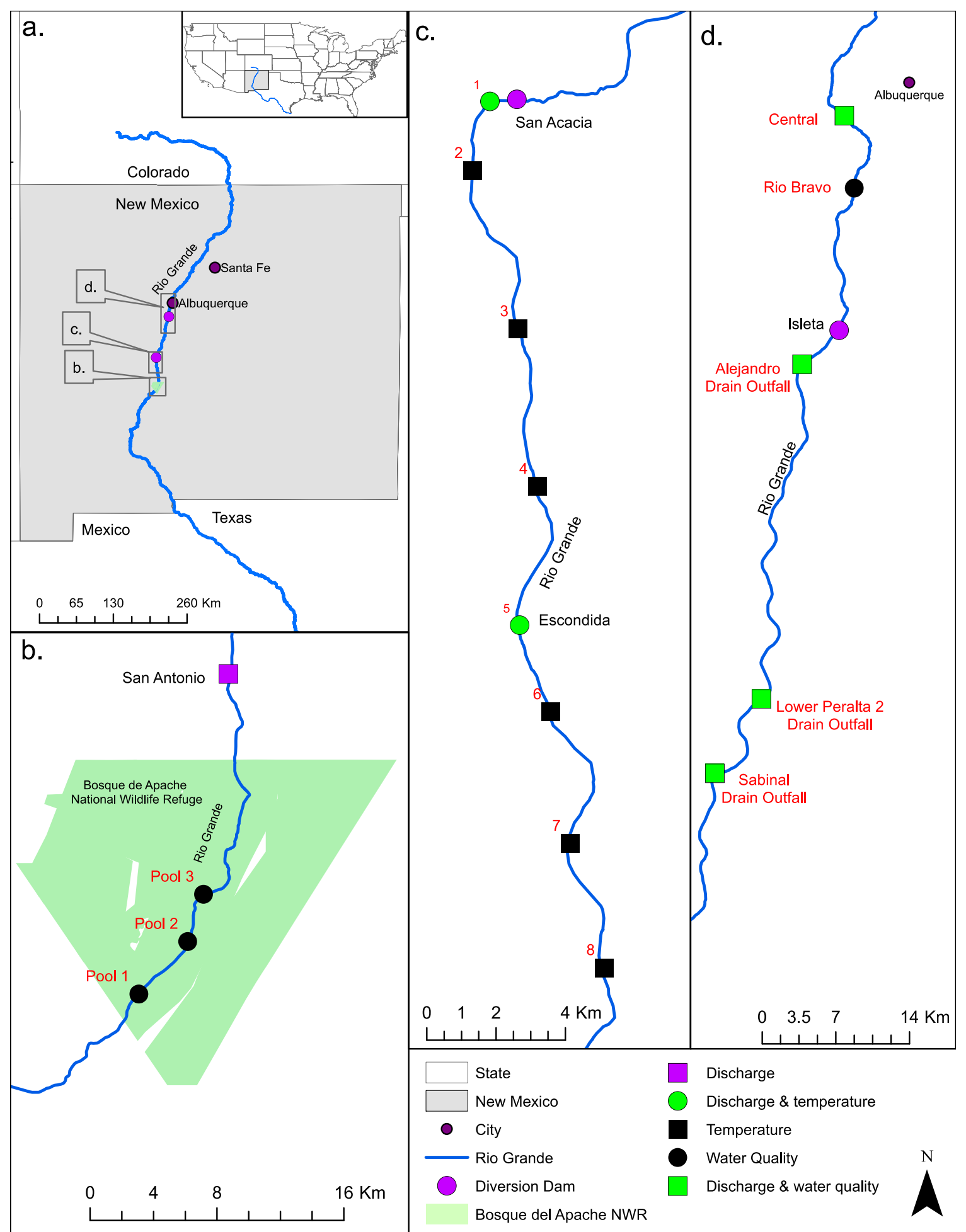

Fig. 1. Maps showing the Rio Grande and the study area in the Middle Rio Grande in central New Mexico. Panel (a) depicts the Rio Grande, major cities, the Isleta and San Acaica Diversion dams, and Bosque del Apache National Wildlife Refuge in New Mexico, USA. Panel (b) shows the Rio Grande, Bosque del Apache National Wildlife Refuge, USGS streamflow gage near San Antonio (No. 08355490), and isolated pools where the water quality sondes were deployed and discrete water samples were collected. Panel (c) shows the location of the Rio Grande, San Acacia Diversion Dam, locations of deployed temperature loggers, USGS streamflow gages below San Acacia (No. 08354900) and Escondida (No.83555050). Panel (d) shows the Rio Grande, Isleta Diversion Dam, USGS streamflow gage (No. 08354900) and water quality sonde on the Rio Grande at Central Bridge, a water quality sonde on the Rio Grande at Rio Bravo Bridge, and select drain outfalls where discharge was measured and water quality sensors were deployed upstream of the confluence with the Rio Grande. 
$\left(34^{\circ} 52^{\prime} 45.7392^{\prime} \mathrm{N} ; 106^{\circ} 43^{\prime} 4.962^{\prime} \mathrm{W}\right)$ drains (Fig. 1). We chose these drains due to their proximity to perennial reaches of the river and because they have been identified by local managers as potential emergency refuges to be utilized during river drying. The drains receive shallow groundwater and surface water inputs from upstream diversions, adjacent flood irrigation operations, and episodic pulses of stormwater following monsoon events (McAda and Barroll, 2002). We compared the water quality in these outfalls to water quality in the mainstem of the river at 1 of 2 water quality stations located upstream of the outfalls (Fig. 1; Central $35^{\circ} 05^{\prime} 21^{\prime} \mathrm{N}$; $106^{\circ} 40^{\prime} 50.5^{\prime} \mathrm{W}$, or Rio Bravo $35^{\circ} 1^{\prime} 38.136^{\prime} \mathrm{N}$; $\left.106^{\circ} 40^{\prime} 21.72^{\prime} \mathrm{W}\right)$. Data were collected from 08 August 2013 to 08 September 2013 and from 25 July 2014 to 12 August 2014 in the Sabinal Drain, and from 25 July 2014 to 12 August 2014 and 04 June 2015 to 27 August 2015 in the LP2 and Alejandro drains. Water temperature, dissolved oxygen (DO), $\mathrm{pH}$, turbidity, and specific conductance (SC) were recorded at 15-minute increments using a Yellow Springs Instrument (YSI) EXO1 or EXO2 multi-parameter sonde at all sites except for the Sabinal Drain. At this station, an Instrumentation Northwest (INW) Aquistar DO sensor and CT2X SC-temperature sensor were deployed in 2013 and a HOBO Pendant temperature sensor (Onset Computer Corporation) was deployed in 2014. Site visits were made to all instruments in both the drains and the mainstem of the river at two to four week intervals to clean and calibrate the sensors following USGS standard operating procedures (Wagner et al., 2006). Water quality data were compiled and validated using Aquarius Time-Series 3.10 (Aquatic Informatics, Vancouver, British Columbia, Canada). Data were corrected for fouling and calibration drift using data collected in the field.

The water temperature and DO time series data were analyzed using the micompr package (Fachada et al., 2016) implemented in R (R Core Team, 2017). Briefly, daily max and min values were used in a principal component analysis to transform the observations into linearly uncorrelated statistical measures. Multivariate analysis of variance (MANOVA) and adjusted $t$-tests were then used to test for differences between sites (Fachada et al., 2016).

\subsection{Isolated pools}

Continuous and discrete water quality data were collected in three isolated pools that formed in the San Acacia reach during July 2016. Pools were chosen at or near locations where pools persisted for extended periods during previous years. The pools were located within the Bosque del Apache National Wildlife Area (Fig. 1) to ensure the security of the water quality sensors. Pools 1, 2, and 3 were located at $\left(33^{\circ} 44^{\prime} 17.1672^{\prime} \mathrm{N}\right.$; $\left.106^{\circ} 54^{\prime} 10.908^{\prime} \mathrm{W}\right),\left(33^{\circ} 46^{\prime} 3.738^{\prime} \mathrm{N} ; 106^{\circ} 52^{\prime} 32.862^{\prime} \mathrm{W}\right)$, and $\left(33^{\circ} 47^{\prime} 40.992^{\prime} \mathrm{N} ; 106^{\circ} 51^{\prime} 59.3748^{\prime} \mathrm{W}\right)$. Continuous data was collected to determine if critical thresholds for RGSM survival are exceeded in these potential refuges. A YSI EXO2 or $6920 \mathrm{~V} 2$ sonde was deployed at the deepest point of each pool and measurements of temperature, conductivity, $\mathrm{DO}, \mathrm{pH}$, and turbidity were collected at 15-minute intervals until either pool drying (four days for pools 2 and 3 ) or river reconnection occurred (21 days for
Pool 1). The instruments were calibrated, and the data was processed using the methods described above. Continuous data were analyzed to determine the number of measurements where DO or temperature exceeded critical thresholds for RGSM survival.

Discrete water chemistry data were collected to determine if pools were receiving shallow groundwater inputs that replenish evaporative losses and to assess biogeochemical processes that may impact water quality in these potential refuges. Samples were collected in triplicate on seven, four, and three collection dates for pools 1,2, and 3, respectively, with sampling points distributed over the duration of the pool persistence. A peristaltic Geotech Geopump ${ }^{\mathrm{TM}}$ was used to filter water through a $0.45 \mu \mathrm{m}$ cellulose nitrate membrane filter for anions, cations (acidified with nitric acid), and deuterium and $\mathrm{H}_{2}{ }^{18} \mathrm{O}$ (stored with no headspace). Anion samples were analyzed using Ion Chromatography (Dionex ICS 1100). Cation samples were analyzed using an Inductively Coupled Plasma-Atomic Emission Spectrometer (PerkinElmer Optima 5300DV) with the instrument optimized using $\mathrm{Hg}$ alignment for the optics and Mn view alignment for the wavelengths. Deuterium ( $\delta \mathrm{D})$ and $\mathrm{H}_{2}{ }^{18} \mathrm{O}\left(\delta^{18} \mathrm{O}\right)$ were analyzed using a Picarro L1102-I Water Isotopic Analyzer for simultaneous hydrogen and oxygen isotope analyses from liquid water. Alkalinity was determined using titration with $0.02 \mathrm{~N} \mathrm{H}_{2} \mathrm{SO}_{4}$ and phenolphthalein and Bromocresol-green Methyl-red indicators.

\subsection{Reaches below diversion dams}

Continuous water temperature data was collected in a perennial reach of river downstream of a diversion dam to determine if critical thresholds for RGSM survival are exceeded in this reach. Eight submersible silicone iButton sensors (iBWetLand-22L, Alpha Mach Inc.) were deployed at $\sim 1 \mathrm{~km}$ intervals in a $\sim 9 \mathrm{~km}$ reach below the dam (Fig. 1), beginning on 31 May 2018 and ending on 09 August 2018. The iButton sensors were deployed at $\sim 60 \%$ stream depth in white PVC flow-through tubes that shaded the sensors from solar radiation. Sensors were deployed in areas with high velocity flow, maximum depth and near the west bank of the river. Sensors were cleaned and downloaded at $\sim 3$-week intervals. During one site visit, temperature profiles were collected along a transect perpendicular to flow at four sites $(1,2,3$, and 5) to determine if temperatures at the sensor locations were representative of conditions at a given cross section. Additionally, a YSI EXO2 sonde was deployed at the upstream most site (immediately downstream of the diversion dam). The sonde was calibrated, and the data was processed using the methods described above. Continuous data from the temperature sensors were analyzed to determine the number of measurements where temperature exceeded critical thresholds for fish survival. Additionally, between station variation in continuous data was assessed using the micompr package described above (Fachada et al., 2016).

\section{Results}

\subsection{Agricultural return drains}

Water temperature in all drain outfalls during all years was consistently lower than the temperature in the mainstem of the 

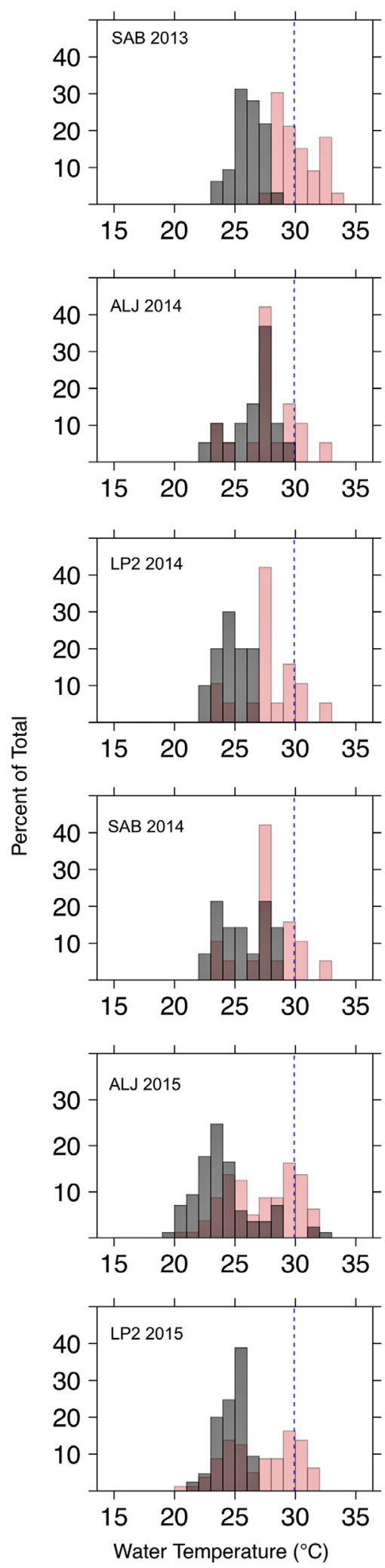

Fig. 2. Histograms of the distribution of water temperatures for the mainstem of the Rio Grande (red) and the agricultural return drains (gray) during the same period. The RGSM no acute lethal level (NALL) is designated by the vertical blue dashed line. river (Fig. 2, Tab. 1). In particular, maximum water temperatures were approximately 3,5 , and $6{ }^{\circ} \mathrm{C}$ lower than the mainstem in the Alejandro, Sabinal, and LP2 drains, respectively. Between year differences for temperature distributions were minimal in the drains (Fig. 2), while between site differences were apparent with the LP2 Drain Outfall being the coolest (mean and maximum temperatures of $\sim 23$ and $26.7^{\circ} \mathrm{C}$, respectively, Tab. 1) and the Alejandro Drain outfall being the warmest (mean and maximum temperatures of $\sim 22.5$ and $30.9^{\circ} \mathrm{C}$, respectively, Tab. 1). Additionally, we observed temperatures exceeding the no acute lethal level (NALL) for the Rio Grande Silver Minnow $\left(29.9^{\circ} \mathrm{C}\right.$, Buhl, 2020 ) for only $0.4 \%$ of the temperature observation during a single year in a single drain outfall (Alejandro Drain, 2015). In contrast, during each year of data collection, temperatures in the mainstem of the river exceeded the NALL, with the percentage of exceedances ranging from 2.5 to $7.8 \%$ of the total number of observations in 2015 and 2013, respectively (Fig. 2, Tab. 1). Results from the micompr analysis suggest that all mainstem versus drain outfall temperature comparisons were significantly different (Adjusted $t$-test, $P<0.01$ ) with the exception of the Alejandro Drain in 2014.

Concentrations of DO in the return drains were more variable than water temperature, with some sites having higher, and other sites lower values than the mainstem. DO values in the Alejandro Drain Outfall were low (across year average mean and minimum values of 4.89 and $0.48 \mathrm{mg} \mathrm{L}^{-1}$, respectively), while mean and minimum values in the LP2 and Sabinal drain outfalls were $\sim 6.5 \mathrm{mg} \mathrm{L}^{-1}$ or higher (Fig. 3, Tab. 1). In comparison, DO minimum and mean values in the mainstem averaged 5.37 and $7.45 \mathrm{mg} \mathrm{L}^{-1}$, respectively (Fig. 3, Tab. 1). The Alejandro Drain Outfall was the only drain outfall or mainstem site that was consistently below the no acute lethal concentration (NALC) for the Rio Grande Silver Minnow (4.4 $\mathrm{mg} \mathrm{L}^{-1}$, personal communication from $\mathrm{K}$ Buhl, U.S. Geological Survey) for 11.7 and $46.4 \%$ of the total observations in 2014 and 2015, respectively (Fig. 3, Tab. 1). No DO values were below the NALC in either the Sabinal or the LP2 drains, and only $0.2 \%$ of the total observations in the mainstem of the river were below the NALC. DO and temperature were inversely related in the Sabinal and LP2 drains and in the mainstem of the MRG, however, these variables co-varied in the Alejandro Drain Outfall. Results from the micompr analysis suggest that all mainstem versus drain outfall DO comparisons were significantly different (Adjusted $t$-test, $P<0.01$ ).

\subsection{Isolated pools}

Of the three pools in which we assessed water quality, two dried within four days (pools 2 and 3) while the third pool (Pool 1) persisted for 21 days, albeit with dramatically reduced surface area $\left(\sim 0.6 \mathrm{~m}^{2}\right)$ prior to reconnection with the river when a storm event resulted in a flow pulse (Fig. 4). The water quality between pools varied considerably during the four days when all three pools remained wetted (Fig. 4, Tab. 2). Water temperature in Pool 1 was low and relatively constant throughout this period (mean, maximum, and standard 
Table 1. Summary data for water quality in the drain outfalls.

\begin{tabular}{llllllllll}
\hline Drain Outfall & River.13 & River.14 & River.15 & Alej.14 & Alej.15 & LP2.14 & LP2.15 & Sab.13 & Sab.14 \\
\hline Total Temp Readings & 3055 & 1824 & 7502 & 1824 & 8158 & 1920 & 8159 & 1439 & 672 \\
Total Temp Readings Over NALL & 238 & 48 & 190 & 0 & 32 & 0 & 0 & 0 \\
Pct. of Total Temp & 7.79 & 2.63 & 2.53 & 0.00 & 0.39 & 0.00 & 0.00 & 0.00 & 0.00 \\
Temp Min & 16.65 & 18.44 & 17.76 & 17.38 & 17.46 & 18.28 & 19.05 & 17.63 & 20.23 \\
Temp Max & 33.13 & 32.54 & 31.97 & 29.47 & 32.36 & 26.78 & 26.69 & 28.49 & 28.26 \\
Temp Mean & 24.13 & 24.03 & 24.26 & 23.08 & 22.18 & 23.07 & 23.06 & 22.86 & 23.47 \\
Temp Std & 3.73 & 2.81 & 2.73 & 2.38 & 1.87 & 1.65 & 1.63 & 2.34 & 1.94 \\
Total DO Readings & 2568 & 1773 & 7430 & 1824 & 8099 & 1920 & 8158 & 1439 & NA \\
Total DO Readings Under NALC & 0 & 4 & 0 & 213 & 3755 & 0 & 0 & 0 \\
Pct. of Total DO & 0.00 & 0.23 & 0.00 & 11.68 & 46.36 & 0.00 & 0.00 & 0.00 & NA \\
DO Min & 5.90 & 4.33 & 5.91 & 0.96 & 0.00 & 6.47 & 6.52 & 7.88 & NA \\
DO Max & 10.58 & 7.35 & 8.19 & 8.12 & 8.88 & 7.39 & 8.73 & 9.69 & NA \\
DO Mean & 8.54 & 6.35 & 7.46 & 5.49 & 4.28 & 6.90 & 7.15 & 8.76 & NA \\
DO Std & 0.76 & 0.49 & 0.52 & 1.11 & 1.76 & 0.21 & 0.25 & 0.39 & NA \\
\hline
\end{tabular}

deviation of $21.6,22.9,0.46^{\circ} \mathrm{C}$, respectively), with no observations exceeding the NALL. Maximum water temperatures in pools 2 and 3 reached 29.7 and $34^{\circ} \mathrm{C}$, respectively, with $\sim 22 \%$ of the observations for Pool 3 exceeding the NALL for the RGSM (Fig. 4, Tab. 2). DO levels in Pool 1 were consistent and all values were above the NALC for the RGSM (mean of $7.11 \mathrm{mg} \mathrm{L}^{-1}$, standard deviation of $0.06 \mathrm{mg} \mathrm{L}^{-1}$ ). In contrast, DO concentrations in pools 2 and 3 were low (mean values of 1.9 and $0.43 \mathrm{mg} \mathrm{L}^{-1}$, respectively) and 89.4 and $100 \%$ of the observations, respectively, were below the RGSM NALC. During the remaining 17 days that Pool 1 persisted, temperatures remained low and DO never declined below $5 \mathrm{mg} \mathrm{L}^{-1}$ (Fig. 5).

Discrete samples from Pool 1 during the 21-day period prior to reconnection revealed an overall increase in $\delta \mathrm{D}$ values during the sampling period, with a rapid initial rise followed by a gradual increase during the final seven days of sampling (Fig. 6). While $\mathrm{Cl}$ values remained relatively stable during this period, concentrations of $\mathrm{SO}_{4}{ }^{2-}$ declined by 40 fold, leading to a sharp decline in the $\mathrm{SO}_{4}: \mathrm{Cl}$ ratio (Fig. 6). In pools 2 and 3, similar increases in $\delta \mathrm{D}$ and decreases in $\mathrm{SO}_{4}: \mathrm{Cl}$ ratios were observed, however, $\mathrm{Cl}$ values also increased rapidly during drying (Fig. 6).

\subsection{Reaches below diversion dams}

Water temperatures downstream of the diversion dam changed predictably and dramatically with downstream distance. While the mean values were consistent between sites, the diurnal variability increased with distance from the dam (average daily amplitude of $\sim 5^{\circ} \mathrm{C}$ at Site 1 and $\sim 15^{\circ} \mathrm{C}$ at Site 8 , Fig. 7 , Tab. 3 ). Thus, $\sim 0.2 \%$ of the total observations at Site 1 but $\sim 21 \%$ of the observations at sites 7 and 8 exceeded the NALL for the RGSM as did most of the daily maximum values for sites 3 through 8 (Fig. 7). At the downstream sites, the total degree days for maximum and minimum water temperature were very similar to those for air temperature (Fig. 7). Temperature transects at four sensor locations confirm that temperatures were relatively consistent for each cross section. Results from the micompr analysis suggest that water temperatures from sites 1,3 and 8 were all significantly different (adjusted $P$-value for $t$-test $<0.01$ ), however, downstream sites including 5,7 , and 8 were not significantly different from one another (adjusted $P$-value for $t$-test $>0.05$ ). Other water quality parameters immediately downstream of the diversion dam suggest relatively high water quality in this reach: only 12 hours of DO values below the RGSM NALC for DO were recorded during the 40 days of data collection and no water temperatures were recorded outside of the NALL during this period.

\section{Discussion}

The extensive extinction and extirpation (7 and $40 \%$ of the endemic species) of native fish species in the MRG suggests that over the past century, the altered flow regime, declines in water availability, disconnection from the floodplain, and river fragmentation are cumulatively creating conditions that exert substantial stress on endemic fish populations. Climate change impacts are predicted to further decrease water supply in the southwestern United States, reducing water availability while simultaneously increasing anthropogenic demand. Thus, while there is a need for refuge habitat in the MRG and other drought prone rivers to sustain fish populations in the face of increasing stressors, little is known about water quality within potential refuges. In this study, we document widely varying water quality conditions both within and among three types of potential refuges, with significant implications for the suitability of potential refuges to support fish populations.

\subsection{Refuge characteristics that support habitability}

When considered across habitats, the three specific characteristics that appear to be most influential in providing suitable water quality to sustain fish populations within a given location are: cool seepage inputs, low surface-area-to-volume or width-to-depth ratios, and riparian shading. These characteristics were present in a subset of the replicates (drain outfalls, isolated pools), or in a longitudinal portion (river reach below diversion dam), of each of the refuge types studied here. 

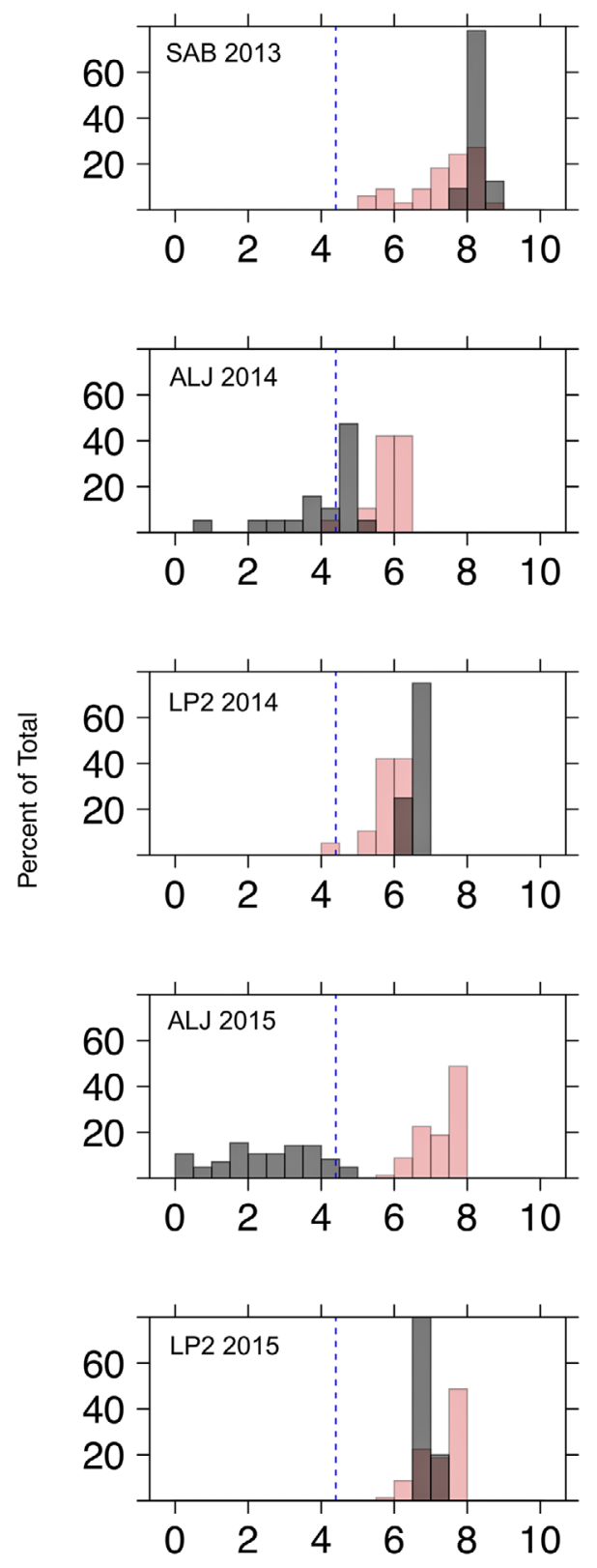

Daily minimum dissolved oxygen $\left(\mathrm{mg} \mathrm{L}^{-1}\right)$

Fig. 3. Histograms of the distribution of dissolved oxygen for the mainstem of the Rio Grande (red) and the agricultural return drains (gray) during the same period. The RGSM no acute lethal concentration (NALC) is designated by the vertical blue dashed line.

In the agricultural return drain outfalls, temperatures were lower than in the mainstem of river and values exceeding the NALC for the RGSM were very rare, likely due to shallow groundwater seepage from irrigation supply ditches and infiltration from flood irrigation (Fernald and Guldan, 2006; Gutiérrez-Jurado et al., 2017; Ochoa et al., 2012). Both processes create hydrologic gradients that facilitate the movement of cool groundwater into drainage ditches (Caissie, 2006; Helmus et al., 2009). Additionally, the irrigation ditches are narrow, have low width to depth ratios, and are frequently
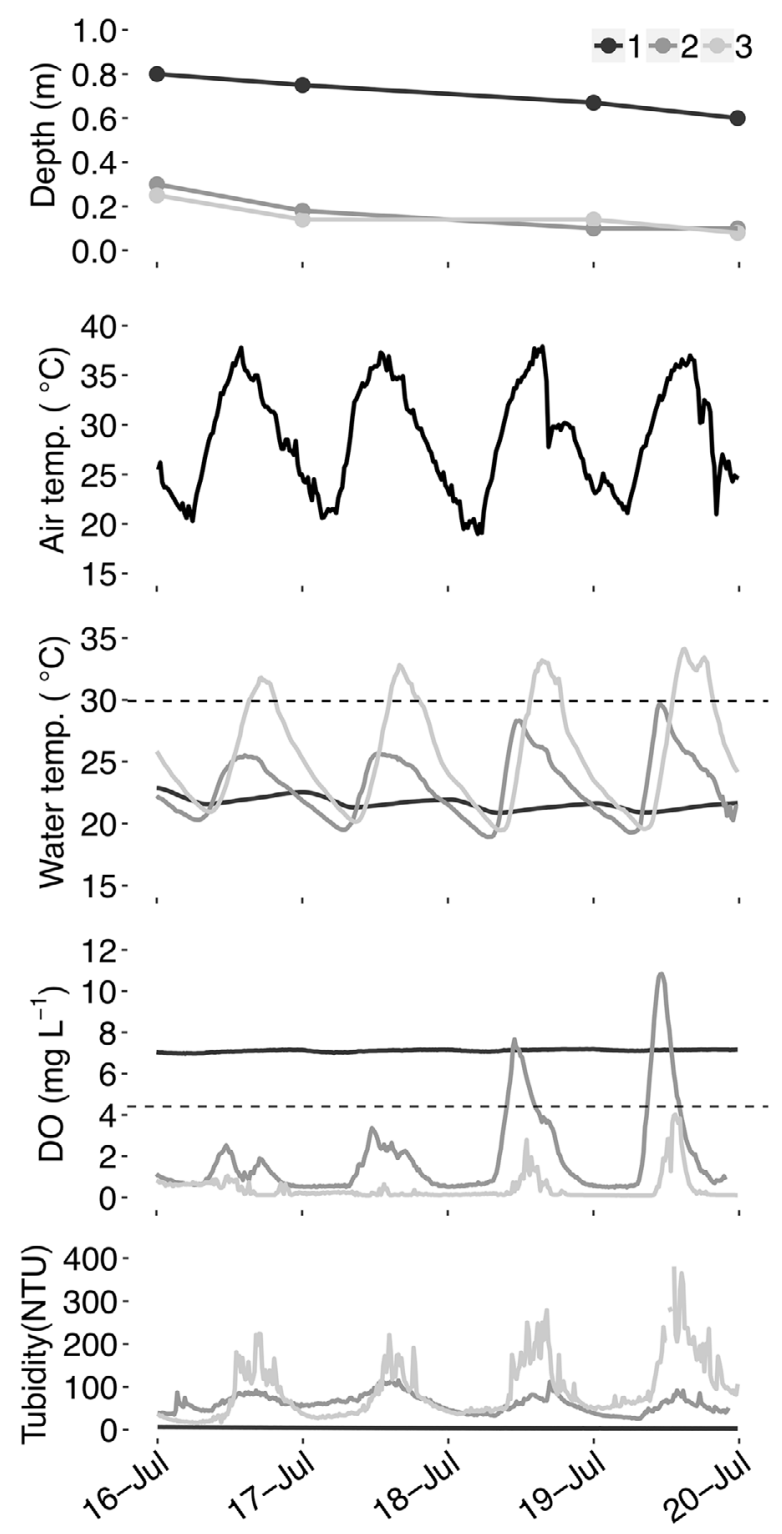

Fig. 4. Hydrologic and water quality monitoring in three isolated pools in the MRG that formed following river intermittency (16 July 2016 to 20 July 2016). Pool depth (m) was measured at the location of the sonde, with labeled points representing the number of days after intermittency. Air temperature $\left({ }^{\circ} \mathrm{C}\right)$ was measured at approximately 30-minute increments from the Socorro municipal airport. Water temperature $\left({ }^{\circ} \mathrm{C}\right)$, dissolved oxygen $\left(\mathrm{DO} ; \mathrm{mg} \mathrm{L}^{-1}\right)$, and turbidity (NTU) were measured at 15 -minute increments following pool formation until drying prevented sample collection. The RGSM no acute lethal concentration (NALC) for DO and no acute lethal level (NALL) for water temperature are designated by horizontal black dashed lines.

lined with riparian vegetation, all of which promote reduced water temperatures (Caissie, 2006). Further, in two of the outfalls (Sabinal and LP2; SI 11) these low temperatures appear to have contributed to high DO values due to physical controls of the solubility of oxygen in water (Wetzel, 2001). 
Table 2. Summary data for water quality in the isolated pools.

\begin{tabular}{llll}
\hline Isolated Pool & Pool 1 & Pool 2 & Pool 3 \\
\hline Total Temp Readings & 384 & 384 & 384 \\
Total Temp Readings Over NALL & 0 & 0 & 84 \\
Pct. of Total Temp Over NALL & 0.00 & 0.00 & 21.88 \\
Temp Min & 20.86 & 18.93 & 19.45 \\
Temp Max & 22.87 & 29.68 & 34.12 \\
Temp Mean & 21.62 & 22.97 & 25.54 \\
Temp Std & 0.46 & 2.54 & 4.25 \\
Total DO Readings & 384 & 376 & 384 \\
Total DO Readings Under NALC & 0 & 336 & 384 \\
Pct. of Total DO Under NALC & 0.00 & 89.36 & 100.00 \\
DO Min & 6.96 & 0.49 & 0.11 \\
DO Max & 7.20 & 10.84 & 4.01 \\
DO Mean & 7.11 & 1.90 & 0.43 \\
DO Std & 0.06 & 2.08 & 0.61 \\
\hline
\end{tabular}

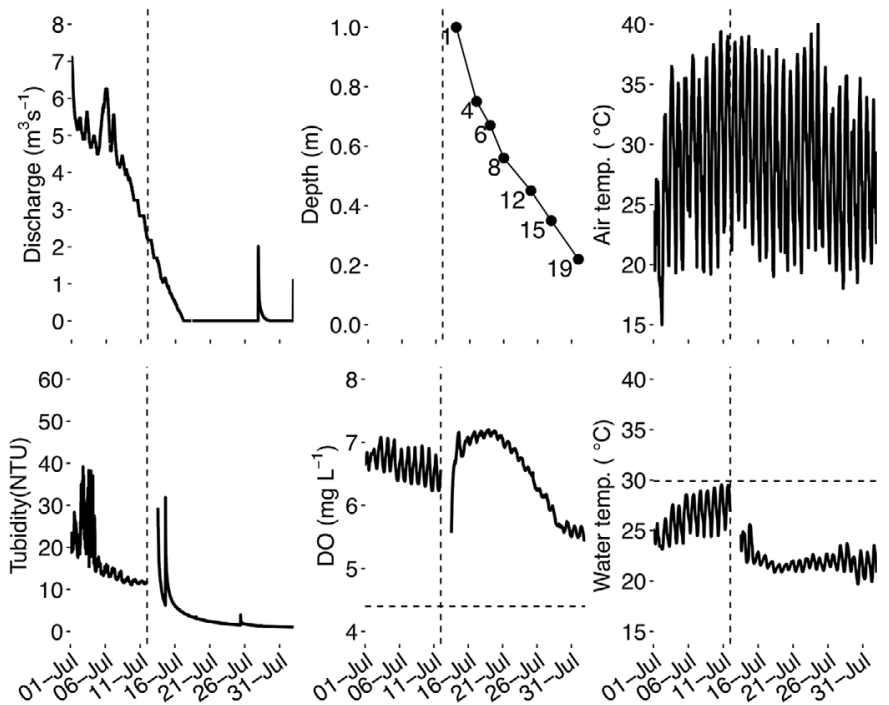

Fig. 5. Hydrologic, atmospheric, and water quality monitoring in the Rio Grande prior to (01 July 2016 to 11 July 2016) and following river intermittency and the formation of Pool 1 (13 July 2016 to 01 August 2016). River discharge $\left(\mathrm{m}^{3} \mathrm{~s}^{-1}\right)$ was measured approximately $23 \mathrm{~km}$ upstream (USGS No. 08355490). Pool depth (m) was measured at the location of the sonde, with labeled points representing the number of days after intermittency (vertical black dashed line). Air temperature $\left({ }^{\circ} \mathrm{C}\right)$ was measured approximately $31 \mathrm{~km}$ from the deployed sonde at the Socorro Municipal Airport. Turbidity (NTU), dissolved oxygen (DO; $\mathrm{mg} \mathrm{L}^{-1}$ ), and water temperature $\left({ }^{\circ} \mathrm{C}\right)$ were measured in proximity (less than three $\mathrm{km}$ ) to Pool 1 prior to intermittency and within Pool 1 after intermittency. The RGSM no acute lethal concentration (NALC) for DO and no acute lethal level (NALL) for water temperature are designated by horizontal black dashed lines.

Thus, as in other regions (Colvin et al., 2009; Herzon and Helenius, 2008), the agricultural irrigation system in the MRG may sustain native fish populations during periods of low flow and drought. These findings support previous observations and

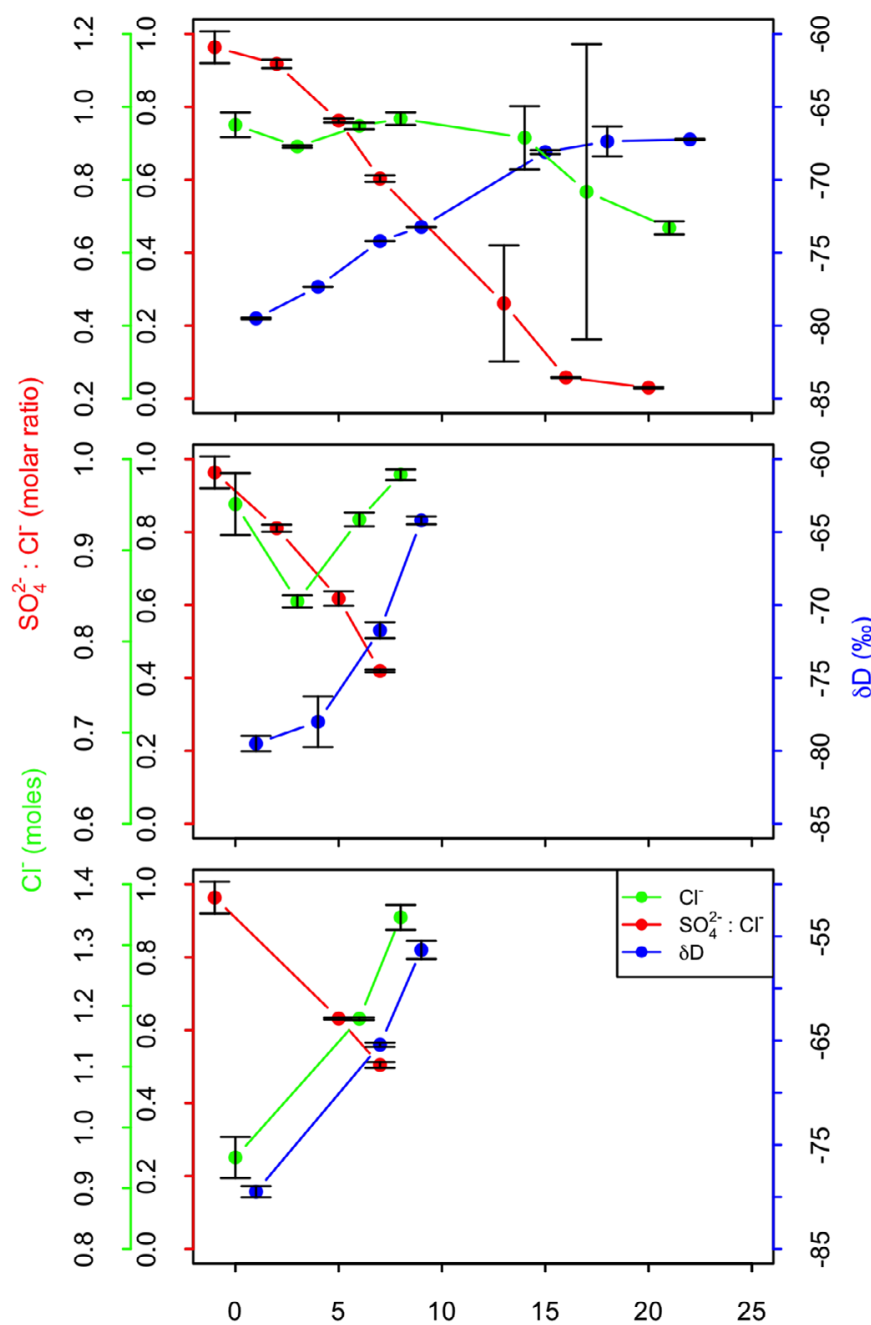

Fig. 6. Discrete data for $\mathrm{Cl}^{-}, \delta \mathrm{D}$ and the $\mathrm{SO}_{4}{ }^{2-}: \mathrm{Cl}$ ratio for pools 1,2 , and 3. Data points for discrete data were horizontally offset (i.e., $\delta \mathrm{D}-1$ day and $\mathrm{SO}_{4}{ }^{2-}: \mathrm{Cl}+1$ day) to reduce overlap and facilitate viewing.

studies in the MRG which have documented the presence of native fish in portions of the irrigation system (Lang and Altenbach, 1994) and have identified a drain outfall as a potential source community for recolonization of the mainstem of the river following drying (Cowley et al., 2007). However, as discussed below, caveats and exceptions exist when considering these features as refuges for fish populations.

Two characteristics, surface-to-volume ratio and shading were also important in the persistence of the single isolated pool from this study that lasted for more than a few days. These attributes also likely contributed to the low water temperature and high DO observed in this pool, with values that never exceeded critical thresholds for RGSM. This finding could be interpreted as evidence that a subset of isolated pools in the MRG provide suitable refuge during low flow periods, as is common in other river systems (Parkos et al., 2011; Pires et al., 2010; Rayner et al., 2009). However, the absence of groundwater inputs (see discussion below), the very limited 
D.J. Van Horn et al.: Knowl. Manag. Aquat. Ecosyst. 2022, 423, 7
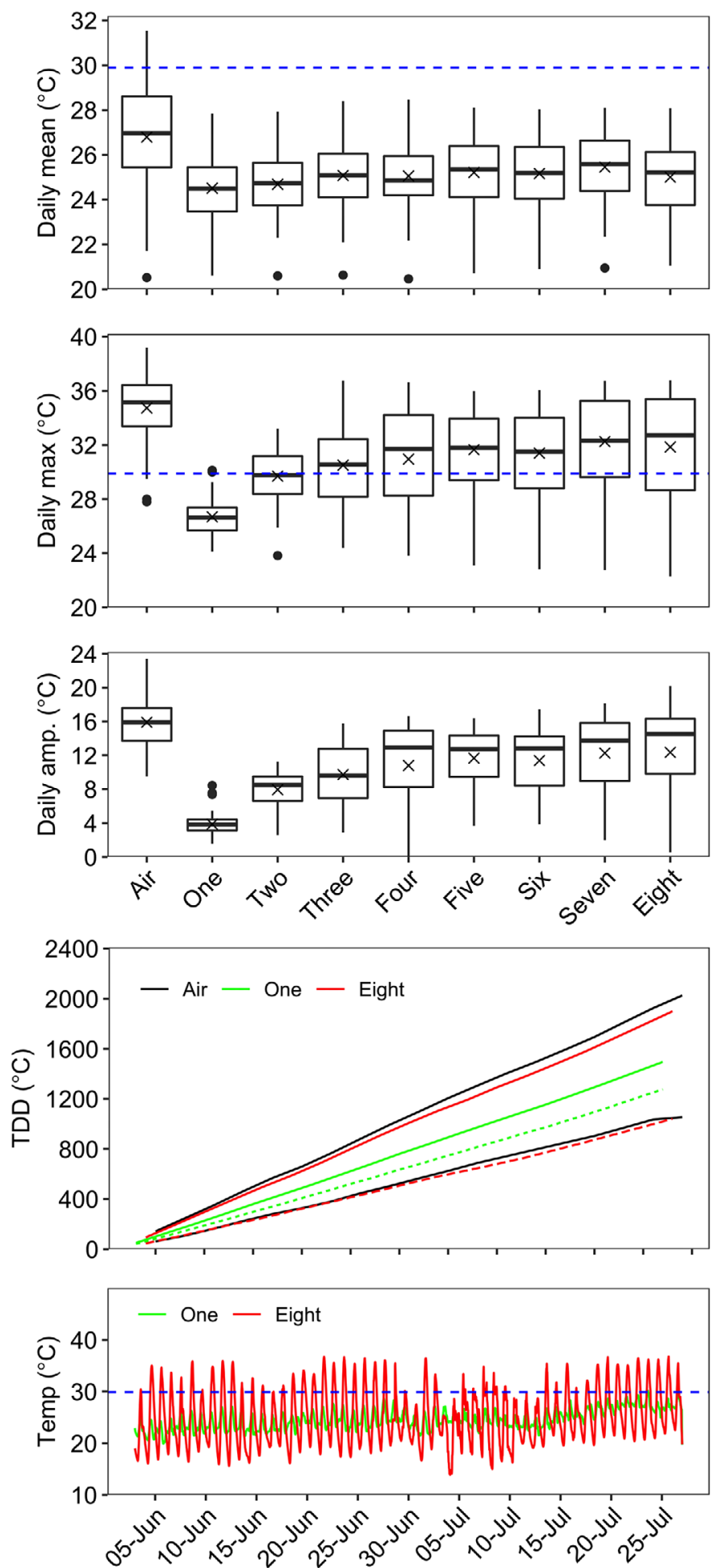

Fig. 7. Daily (0000-2330 hours) mean, maximum, and amplitude of air temperature and water temperature measured at $\sim 1 \mathrm{~km}$ intervals in a $\sim 9 \mathrm{~km}$ reach of the Rio Grande below San Acacia Diversion Dam (Fig. 1), beginning on 31 May 18 and ending on 09 August 18. Cumulative total degree days (TDD) for daily mean (solid lines) maximum (dashed lines) for air along with the upstream (One) and downstream most (Eight) water temperature stations. Water temperature measured at 30-minute increments at the upstream and downstream most station beginning on 03 June 18 and ending on 27 July 18 . Water temperature station name represents the approximate distance $(\mathrm{km})$ below the dam. Air temperature $\left({ }^{\circ} \mathrm{C}\right)$ was measured at approximately 30 -minute increments from the Socorro municipal airport. The RGSM no acute lethal concentration (NALC) is designated by the horizontal blue dashed line. 
D.J. Van Horn et al.: Knowl. Manag. Aquat. Ecosyst. 2022, 423, 7

Table 3. Summary data for water temperature below the San Acacia Diversion Dam.

\begin{tabular}{|c|c|c|c|c|c|c|c|c|c|}
\hline Temperature logger & Air & One & Two & Three & Four & Five & Six & Seven & Eight \\
\hline Total temp readings over NALL & 931 & 5 & 230 & 354 & 530 & 525 & 495 & 594 & 568 \\
\hline Pct. of total & 34 & 0 & 8 & 12.94 & 19.37 & 19.19 & 18.09 & 21.71 & 20.76 \\
\hline Temp min & 13.28 & 19.88 & 18.82 & 16 & 15.44 & 15.73 & 15.81 & 15.42 & 13.89 \\
\hline Temp max & 39.08 & 30.13 & 33.19 & 36.74 & 36.62 & 35.98 & 36.06 & 36.73 & 36.76 \\
\hline Temp mean & 26.98 & 24.45 & 24.59 & 25.11 & 25.3 & 25.23 & 25.16 & 25.46 & 24.97 \\
\hline Temp Std & 5.75 & 1.94 & 3.30 & 3.99 & 4.65 & 4.56 & 4.51 & 4.98 & 5.27 \\
\hline
\end{tabular}

areal extent of the pools that do persist, shallow depth, and the highly transient nature of the vast majority of pools in the MRG (Archdeacon and Reale, 2020) all suggest that this refuge type is likely to be of limited utility in maintaining populations of at risk fishes.

Previous studies have documented the importance of river segments that maintain flow during periods of drought as refuge for aquatic organisms (Rolls et al., 2012). The river reach immediately downstream of the San Acacia Diversion Dam is deeply incised, and even when the dam gates are fully closed, as they were during this study, leakage from around the gates and groundwater seepage from associated irrigation canals and drains (S.S. Papadopulos \& Associates, 2001) provide sustained flows of $\sim 0.135 \mathrm{~m}^{3} \mathrm{sec}^{-1}$ in the main channel (USGS 08354900, Rio Grande Floodway at San Acacia, NM). Both sources of flow provide low temperature water to this reach, creating a thermal refuge, as occurs below other dams with hypolimnetic release structures (Olden and Naiman, 2010) and in areas receiving shallow groundwater inputs associated with irrigation drains (Caissie, 2006; Helmus et al., 2009). Thus, cool seepage water is the crucial characteristic that creates habitability immediately downstream of the dam. However, as discussed below, due to an absence of the other two characteristics, low width-to-depth ratios and shading, this refuge is limited in spatial extent.

\subsection{Contexts in which refuge habitability was reduced and ecological traps may occur}

For each of the three types of refuge habitats investigated in this study, a subset of the potential locations had water quality that was not suitable to support imperiled fishes during river drying. These locations either had a reduced incident of the key characteristics described above, or additional factors that negatively impacted suitability. Understanding these exceptions to habitability is important, both for making management decisions and in understanding how some locations may function as ecological traps for individuals seeking refuge.

In the Alejandro Drain outfall, while temperatures were low and conducive to fish habitability, prohibitively low DO values that occurred $\sim 12$ and $46 \%$ of the two summers in which measurements were made, clearly inhibit the viability of this potential refuge and other drain outfalls with similar conditions. Low DO has been linked to high nutrient concentrations in other aquatic ecosystems (Bricker et al., 2008; Camargo and Alonso, 2006) including agricultural drains (Collins et al., 2019), and thus, sampling should be undertaken in the drains in the MRG to determine what characteristics create the observed variability in suitability as potential refuge for fishes. Additionally, it should be noted that for all three drains, other contaminants not measured in this study may preclude these areas as potential refuge habitat. For example, pesticides and potentially toxic trace elements have been documented in the MRG irrigation network (Healy, 1996; Levings et al., 1998), and in sediment samples at mainstem sites, some of which were downstream of irrigation return flows (Marcus et al., 2010). This is notable, as the cooler water temperatures we observed during summer months may attract fishes from the main channel, but become ecological traps due to subsequent exposure to toxins. For example, in another system dwarf galaxias (Galaxiella pusilla) were unable to distinguish between stormwater and non-stormwater wetlands, leading to lower survival and slower maturation in stormwater wetlands (Hale et al., 2018).

The gradual enrichment of $\delta \mathrm{D}$ we observed in all three pools is indicative of evaporative losses without groundwater recharge (Hamilton et al., 2005). Additionally, while one pool persisted, the other two pools dried within four days of formation, and, during the period in which water was present in these pools, the quality was insufficient to support fish communities. Isolated pools in the MRG appear to be dissimilar from those in other river systems where groundwater inputs (Costelloe and Russell, 2014; Labbe and Fausch, 2000) or clay lenses (Hamilton et al., 2005) prevent drying. This is likely due to the highly permeable sand substate found in the southern MRG. Also, the Low Flow Conveyance Channel, which runs parallel to the mainstem of the river and was designed to reduce water loss and increase sediment transport throughout this reach, resulted in the river becoming perched above the conveyance channel (Gorbach, 1999). This modification likely increases drying rates of pools in the river due to seepage into the conveyance channel. Finally, the pools that dried rapidly were shallow and in unshaded portions of the river, providing minimal buffering from solar and thermal inputs. Thus, in contrast to isolated pool formation in other river systems, the majority of pools in the MRG are highly transient, with most pools drying within 4 days of formation (Archdeacon and Reale, 2020). Further, during the drying period water quality quickly become unsuitable for sustaining fish populations, and thus, as reported in some other rivers (Vander Vorste et al., 2020), these pools may become ecological traps that result in complete mortality of fishes seeking refuge.

Finally, our findings suggest that while the basic water quality in the several kilometers of the main channel of the MRG immediately downstream of the San Acacia Diversion is sufficient to support RGSM, as the water moves downstream, water temperature rises quickly due to elevated air temperatures, 
solar input, limited riparian shading, and shallow depths. From approximately three kilometers below the dam to the upstream extent of drying, water temperatures exceed critical limits for the RGSM on a daily basis. This suggests that while ten kilometers of the main channel below the San Acacia Diversion Dam may be perennial, only a subset of this reach is suitable as a refuge. It should also be noted that modifications to the current operation of the San Acacia Diversion Dam could negatively impact this refugium. For example, construction of a fish passage is being planned for this structure in the near future (U.S. Fish and Wildlife Service, 2016), and if this passage delivers warm water from the surface of the impoundment to the downstream reach, the thermal refugium may be compromised. As fishes in this reach can move freely upstream to cooler areas, this potential refuge is unlikely to become an ecological trap.

\section{Conclusions}

Among the habitats examined in this study, isolated pools that persisted through drying were rare and of insufficient size to provide significant refuge for fishes. The irrigation drain returns generally had acceptable water quality for fishes; however long-term effects on growth and reproduction of RGSM should be considered, as well as movements into and out of refuges. Cool water plumes from drains should be large enough to attract and support enough RGSM to be meaningful: the species is short-lived (Horwitz et al., 2018); subject to population crashes and quick recovery (Archdeacon et al., 2020); and likely historically resilient to drought through high demographic resilience. Areas of perennial flow below diversion dams represent the best refuge habitat we examined. Although the entire section of perennial flow did not have favorable temperatures, a large section did have cooler water capable of supporting more fish than either of the other habitat types. This habitat is also in the main river channel and so any RGSM... that use this refuge remain a part of the reproducing population.

These findings suggest that refuge habitability is context dependent, that generalizations regarding the suitability of a specific refuge type should be avoided, and that careful assessment is required to determine if a specific location will support fish assemblages. In the MRG, and in other drought prone rivers, potential refuges that have cool seepage inputs from groundwater or hypolimnetic sources, riparian shading, and low surface-area-to-volume or width-to-depth ratios, should be identified and preserved, or created, to provide habitat during river drying. Careful examination of the potential refuges should be made to ensure they do not function as ecological traps and occur on a scale that matches the behavior and life-history of the species. Finally, the subset of refuges currently habitable may not be suitable in the future due to climate change impacts. As air temperatures rise and anthropogenic water demands accelerate, rates of drying due to evapotranspirative demand will increase, isolated pools will dry more quickly, and groundwater temperatures will rise, impacting refuge in the areas below diversion dams and agricultural return flows.

Acknowledgements. We thank the staff from the U.S. Army Corps of Engineers, U.S. Bureau of Reclamation, U.S. Fish and Wildlife Service New Mexico Ecological Services Field Office, Bosque del Apache National Wildlife Refuge, U.S. Geological Survey New Mexico Water Science Center, Middle Rio Grande Conservancy District, Pueblo of Isleta, New Mexico Interstate Stream Commission, SWCA Environmental Consultants Inc., and Albuquerque Metropolitan Arroyo Flood Control for assistance with scope development, permitting, access, installation, and data collection. The Middle Rio Grande Endangered Species Collaborative Program (U.S. Army Corps of Engineers appropriation, Contract No. W912PP-16-P-0055) and the U.S. Bureau of Reclamation (Interagency Agreement 02-AA-40-8190) provided funding. The findings and conclusions in this article are those of the authors and do not necessarily represent the views of the U.S. Government.

\section{References}

Archdeacon T, Austring T, Diver T, Nolen M. 2013. Fish communities of the Lower Peralta Drain \#2, Lower San Juan Drain, and Sabinal Drain, New Mexico. U. S. Fish and Wildlife Service, Albuquerque, NM, 38. Archdeacon TP. 2016. Reduction in spring flow threatens Rio Grande Silvery Minnow: trends in abundance during river intermittency. Trans Am Fish Soc 145: 754-765.

Archdeacon TP, Diver TA, Reale JK. 2020. Fish rescue during streamflow intermittency may not be effective for conservation of Rio Grande Silvery Minnow. Water 12: 3371.

Archdeacon TP, Reale JK. 2020. No quarter: lack of refuge during flow intermittency results in catastrophic mortality of an imperiled minnow. Freshw Biol 65: 2108-2123.

Bestgen KR, Platania SP. 1990. Extirpation of Notropis simus simus (Cope) and Notropis orca Woolman (Pisces: Cyprinidae) from the Rio Grande in New Mexico, with notes on their life history. Occas Papers Museum Southwestern Biol 6: 1-8.

Bestgen KR, Platania SP. 1991. Status and conservation of the Rio Grande silvery minnow, Hybognathus amarus. Southwest Nat 36: 225-232.

Blythe TL, Schmidt JC. 2018. Estimating the natural flow regime of rivers with long-standing development: the northern branch of the Rio Grande. Water Resour Res 54: 1212-1236.

Braun CL, Pearson DK, Porter MD, Moring JB. 2015. Physical characteristics and fish assemblage composition at site and mesohabitat scales over a range of streamflows in the Middle Rio Grande, New Mexico, winter 2011-12, summer 2012. Scientific Investigations Report. U.S. Geological Survey, Reston, VA, 90-.

Bricker SB, Longstaff B, Dennison W, et al. 2008. Effects of nutrient enrichment in the nation's estuaries: a decade of change. Harmful Algae 8: 21-32.

Buhl KJ. 2020. Relative tolerance of different life stages of Rio Grande silvery minnow to elevated water temperatures. U.S. Geological Survey data release.

Caissie D. 2006. The thermal regime of rivers: a review. Freshw Biol 51: 1389-1406.

Camargo JA, Alonso Á. 2006. Ecological and toxicological effects of inorganic nitrogen pollution in aquatic ecosystems: a global assessment. Environ Int 32: 831-849.

Chester ET, Robson BJ. 2013. Anthropogenic refuges for freshwater biodiversity: their ecological characteristics and management. Biol Conserv 166: 64-75.

Collins SJ, Bellingham L, Mitchell GW, Fahrig L. 2019. Life in the slow drain: landscape structure affects farm ditch water quality. $S c i$ Total Environ 656: 1157-1167. 
Colvin R, Giannico GR, Li J, Boyer KL, Gerth WJ. 2009. Fish use of intermittent watercourses draining agricultural lands in the Upper Willamette River Valley, Oregon. Trans Am Fish Soc 138: 1302-1313.

Costelloe JF, Russell KL. 2014. Identifying conservation priorities for aquatic refugia in an arid zone, ephemeral catchment: a hydrological approach. Ecohydrology 7: 1534-1544.

Cowley DE. 2006. Strategies for ecological restoration of the Middle Rio Grande in New Mexico and recovery of the endangered Rio Grande silvery minnow. Rev Fish Sci 14: 169-186.

Cowley DE, Wissmar RC, Sallenave R. 2007. Fish assemblages and seasonal movements of fish in irrigation canals and river reaches of the middle Rio Grande, New Mexico (USA). Ecol Freshwat Fish 16: $548-558$.

Davey AJ, Kelly DJ. 2007. Fish community responses to drying disturbances in an intermittent stream: a landscape perspective. Freshw Biol 52: 1719-1733.

Davey AJ, Kelly DJ, Biggs BJ. 2006. Refuge-use strategies of stream fishes in response to extreme low flows. J Fish Biol 69: 1047-1059.

Dudley RK, Platania SP, White GC. 2020. Rio Grande Silvery Minnow population monitoring during 2020. American Southwest Ichthyological Researchers, LLC, 1-190.

Fachada N, Rodrigues J, Lopes VV, Martins RC, Rosa AC. 2016. micompr: an $\mathrm{R}$ package for multivariate independent comparison of observations. $R J 8,405-420$.

Fernald AG, Guldan SJ. 2006. Surface water-groundwater interactions between irrigation ditches, alluvial aquifers, and streams. Rev Fish Sci 14: 79-89.

Gorbach C. 1999. History and significance of the Low-Flow Conveyance Channel: what is its future. In: Ortega Klett, C.T. (ed.), Proceedings of the 44th Annual New Mexico Water Conference. New Mexico Water Resources Research Institute, Santa Fe (NM), 156-160.

Gutiérrez-Jurado KY, Fernald AG, Guldan SJ, Ochoa CG. 2017. Surface water and groundwater interactions in traditionally irrigated fields in northern New Mexico, USA. Water 9.

Hale R, Coleman R, Sievers M, Brown TR, Swearer SE. 2018. Using conservation behavior to manage ecological traps for a threatened freshwater fish. Ecosphere 9: e02381.

Halliday BT, Matthews TG, Iervasi D, et al. 2015. Potential for waterresource infrastructure to act as refuge habitat. Ecol Eng 84: 136-148.

Hamilton SK, Bunn SE, Thoms MC, Marshall JC. 2005. Persistence of aquatic refugia between flow pulses in a dryland river system (Cooper Creek, Australia). Limnol Oceanogr 50: 743-754.

Healy DF. 1996. Water-quality assessment of the Rio Grande Valley, Colorado, New Mexico, and Texas; occurrence and distribution of selected pesticides and nutrients at selected surface-water sites in the Mesilla Valley, 1994-95. Water-Resources Investigations Report. U.S. Geological Survey, Albuquerque (NM), 1-92.

Helmus AM, Fernald AG, VanLeeuwen DM, Abbott LB, Ulery AL, Baker TT. 2009. Surface sater seepage effects on shallow groundwater quality along the Rio Grande in northern New Mexico. $J \mathrm{Am}$ Water Resour Assoc 45: 407-418.

Herzon I, Helenius J. 2008. Agricultural drainage ditches, their biological importance and functioning. Biol Conserv 141: 1171-1183.

Hoagstrom CW, Remshardt WJ, Smith JR, Brooks JE. 2010. Changing fish faunas in two reaches of the Rio Grande in the Albuquerque Basin. Southwest Nat 55: 78-89.

Hopper GW, Gido KB, Pennock CA, et al. 2020. Nowhere to swim: interspecific responses of prairie stream fishes in isolated pools during severe drought. Aquat Sci 82: 1-15.

Horwitz RJ, Keller DH, Overbeck PF, Platania SP, Dudley RK, Carson EW. 2018. Age and Growth of the Rio Grande Silvery
Minnow, an Endangered, Short-Lived Cyprinid of the North American Southwest. Trans Am Fish Soc 147: 265-277.

Labbe TR, Fausch KD. 2000. Dynamics of intermittent stream habitat regulate persistence of a threatened fish at multiple scales. Ecol Appl 10: 1774-1791.

Lancaster J, Belyea LR. 1997. Nested hierarchies and scaledependence of mechanisms of flow refugium use. $J N$ Am Benthol Soc 16: 221-238.

Lang BK, Altenbach CS. 1994. Ichthyofauna of the Middle Rio Grande Conservancy District irrigation system: Cochiti Dam to Elephant Butte State Park, July-August 1993. Albuquerque Projects Office, US Bureau of Reclamation, Albuquerque, NM. Albuquerque Projects Office, US Bureau of Reclamation, Albuquerque (NM), 1-92.

Leigh C, Bush A, Harrison ET, et al.2015. Ecological effects of extreme climatic events on riverine ecosystems: insights from Australia. Freshwat Biol 60: 2620-2638.

Levings GW, Healy DF, Richey SF, Carter LF. 1998. Water Quality in the Rio Grande Valley Colorado, New Mexico, and Texas, 1992 1995. U.S. Geological Survey.

Magoulick DD, Kobza RM. 2003. The role of refugia for fishes during drought: a review and synthesis. Freshw Biol 48: 1186-1198.

Marcus MD, Covington S, Liu B, Smith NR. 2010. Use of existing water, sediment, and tissue data to screen ecological risks to the endangered Rio Grande silvery minnow. Sci Total Environ 409: 83-94.

Marshall JC, Menke N, Crook DA, et al. 2016. Go with the flow: the movement behaviour of fish from isolated waterhole refugia during connecting flow events in an intermittent dryland river. Freshw Biol 61: $1242-1258$.

McAda DP, Barroll P. 2002. Simulation of ground-water flow in the Middle Rio Grande basin between Cochiti and San Acacia, New Mexico. Water-Resources Investigations Report. U.S. Geological Survey, Albuquerque (NM), 1-88.

McCallum ES, Nikel KE, Mehdi H, et al. 2019. Municipal wastewater effluent affects fish communities: A multi-year study involving two wastewater treatment plants. Environ Pollut 252: $1730-1741$.

Mehdi H, Lau SC, Synyshyn C, et al. 2021. Municipal wastewater as an ecological trap: Effects on fish communities across seasons. $\mathrm{Sci}$ Total Environ 759: 143430.

Ochoa CG, Fernald AG, Guldan SJ, Tidwell VC, Shukla MK. 2012. Shallow aquifer recharge from irrigation in a semiarid agricultural valley in New Mexico. J Hydrol Eng 18: 1219-1230.

Olden JD, Naiman RJ. 2010. Incorporating thermal regimes into environmental flows assessments: modifying dam operations to restore freshwater ecosystem integrity. Freshwat Biol 55: 86-107.

Parkos JJ, Ruetz CR, Trexler JC. 2011. Disturbance regime and limits on benefits of refuge use for fishes in a fluctuating hydroscape. Oikos 120, 1519-1530.

Patiño-Gomez C, McKinney DC, Maidment DR. 2007. Sharing water resources data in the binational Rio Grande/Bravo Basin. J Water Resour Plan Manag 133: 416-426.

Perkin JS, Gido KB, Costigan KH, Daniels MD, Johnson ER. 2015. Fragmentation and drying ratchet down Great Plains stream fish diversity. Aquat Conserv Mar Freshwat Ecosyst 25: 639-655.

Pires DF, Beja P, Magalhães MF. 2014. Out of pools: movement patterns of Mediterranean stream fish in relation to dry season refugia. River Res Appl 30: 1269-1280.

Pires DF, Pires AM, Collares-Pereira MJ, Magalhães MF. 2010. Variation in fish assemblages across dry-season pools in a Mediterranean stream: effects of pool morphology, physicochemical factors and spatial context. Ecol Freshwat Fish 19: 74-86. 
R Core Team, 2017. R: a language and environment for statistical computing. Vienna, Austria: R Foundation for Statistical Computing. Rayner TS, Jenkins KM, Kingsford RT. 2009. Small environmental flows, drought and the role of refugia for freshwater fish in the Macquarie Marshes, arid Australia. Ecohydrology 2: 440-453.

Rolls RJ, Leigh C, Sheldon F. 2012. Mechanistic effects of low-flow hydrology on riverine ecosystems: ecological principles and consequences of alteration. Freshw Sci 31: 1163-1186.

S.S. Papadopulos \& Associates I. 2001. Assessment of flow conditions and seepage on the Rio Grande and adjacent channels, Isleta to San Marcial, summer 2001. Boulder (CO): S.S. Papadopulos \& Associates, Inc., 305.

U.S. Fish and Wildlife Service, 2016. Final biological and conference opinion for Bureau of Reclamation, Bureau of Indian Affairs, and non-federal water management and maintenance activities on the middle Rio Grande, New Mexico. U.S. Fish and Wildlife Service, Albuquerque (NM).

Vadas RLJ, Beecher HA, Boessow SN, Kohr JH. 2016. Coastal Cutthroat Trout redd counts impacted by natural water supply variations. $N$ Am J Fish Manag 36: 900-912.
Vander Vorste R, Obedzinski M, Nossaman Pierce S, Carlson SM, Grantham TE. 2020. Refuges and ecological traps: Extreme drought threatens persistence of an endangered fish in intermittent streams. Global Change Biol 26: 3834-3845.

Wagner RJ, Boulger RW, Oblinger CJ, Smith BA. 2006. Guidelines and standard procedures for continuous water-quality monitors: station operation, record computation, and data reporting. U.S. Geological Survey, Reston (VA), 96.

Walters AW. 2016. The importance of context dependence for understanding the effects of low-flow events on fish. Freshw Sci 35: 216-228.

Wetzel RG. 2001. Limnology: lake and river ecosystems, Third ed. Academic Press, San Diego (CA). 1006 p.

Worthington TA, Echelle AA, Perkin JS, et al. 2018. The emblematic minnows of the North American Great Plains: a synthesis of threats and conservation opportunities. Fish Fish 19: 271-307.

Zuñiga-Palacios J, Zuria I, Castellanos I, Lara C, Sánchez-Rojas G. 2021. What do we know (and need to know) about the role of urban habitats as ecological traps? Systematic review and meta-analysis. Sci Total Environ 146559.

Cite this article as: Van Horn DJ, Reale JK, Archdeacon TP. 2022. Water quality in three potential drought refuges in an arid-land river: assessing habitat suitability for at-risk fish species. Knowl. Manag. Aquat. Ecosyst., 423, 7. 